\title{
THE ROLE OF INFORMATION TECHNOLOGY IN IMPROVEMENT OF QUALITY OF THE FINANCIAL REPORTS PREPARED BY THE COMMERCIAL BANKS IN BANGLADESH
}

\author{
Dr. Md. Abu Sina \\ Professor \\ Department of Accounting and Information System \\ Islamic University, Kushtia, Bangladesh \\ E-mail: drabusina1970@gmail.com \\ Md. Shahnur Azad Chowdhury \\ Associate Professor \\ Department of Business Administration \\ International Islamic University Chittagong, Bangladesh \\ E-mail: tipu_iiuc@yahoo.com

\section{Md. Tafhim Shakib \\ Research Fellow} \\ Department of Business Administration \\ International Islamic University Chittagong, Bangladesh \\ E-mail: nebulastar333@gmail.com \\ Sultana Akter \\ Assistant Professor \\ Department of Business Administration \\ International Islamic University Chittagong, Bangladesh \\ E-mail: sa_maya@ rocketmail.com
}

\author{
A. B. M. Yasir Arafat \\ Lecturer \\ Department of Computer Science and Engineering \\ International Islamic University Chittagong, Bangladesh \\ E-mail: abmya89@yahoo.com
}

\begin{abstract}
In the $21^{\text {st }}$ century, from bank to insurance, multinational companies to government offices have increased thousands of times their profitability, productivity, sustainability, and also market expansion through the successful uses of ICT. Today another aspect is the preparation of a high-quality financial report that relies entirely on the information. Quality information depends on several characteristics like completeness, accuracy, timeliness, consistency, validity, accessibility, and integrity of that information, etc. Having these characteristics in financial information is the prerequisite for good financial reporting. Usages of IT have a great role in producing quality information and financial
\end{abstract}


reporting consequently. The use of IT in the banking sector is more sophisticated than in other sectors in Bangladesh. Therefore, the purpose of this research is to examine analytically the relationship between the use of Information Technology and the quality of financial reporting. Using primary data sourced a structured questionnaire was administered to selected banks in Bangladesh and data analysis was done through the General Regression Model by OLS method to examine the nature of the relationship that exists between the quality of financial reports and the Adoption of Information Technology. The result of the data analysis of the study showed that a positive correlation exists between IT and the quality of reports.

Keywords: Information Technology, Financial Report, Quality.

JEL Classification Codes: M1, M15, Q55.

\section{INTRODUCTION}

Financial reporting is the tool to interconnect various kinds of financial information that is very much valuable for making a decision related to investment, credit, and other business activities. Usually, it includes general purpose financial statements like balance sheets, income statements, cash flow statements, equity reports, and many other various kinds of statements. It is the method to demonstrate financial data about the flow of funds, financial health, and operating performance of a firm. These are usually published in the company's annual reports. So, it has great importance to the investors to make an investment decision. It is of the same importance for the organization to have an actual position of the firm and plan. So, the report should be standard enough that lead both the investors and the company in the right direction. There are several dimensions of the quality of the repost like as relevance, understandability, reliability, and comparability. Technology helps to enhance the quality of financial reports of today's business using IT like computers, hardware, and software in order to make a decision effectively from strategic to the operational level. Although at the early stage of IT, it was very limited use to accounting system but today's IT is a broader area supporting ERP with business intelligence appliance. Now It is time to conduct research to recognize modern technologies and how they should be used to progress the dimensions of Reporting in terms of relevance, understandability, reliability, comparability, and other quality dimensions.

\section{STATEMENT OF THE PROBLEM}

Financial reporting is publishing the formal records of a company's financial activities. To make a better decision and easy use of these reports, certain standards or qualities should be considered. The qualities include relevance, understandability, reliability, and comparability. Manual procedures always suffer from some sort of limitation like committing an error, taking a long time to prepare the reports, Absence of prompt and quality service, unreliability, Reusability problem, interrupted communication of the reports with the regulatory authorities, etc. Gradually upgrading of Information Technology has brought a dramatic revolution in accounting systems and changed the ecosystem of an economic event. Computer technology has high-velocity processing power through which a lot of data can be processed within a nanosecond. Thus, IT contributed a lot in publishing and preparing financial statements speedier and less costly.

Bangladesh has started its journey towards digitization recently by automating most of its public systems serving the countryman. Private firms started managing the offices in an automated way earlier than the Government initiatives. Most of the firms are now a day's being transformed to automation from manual process which has given speed to the firms and also helped them to be with the era. As the 
processes are still in the inception stage a lot of studies are required to be undertaken to start the journey in an optimum way to draw maximum benefit to save the time that has been elapsed to start. In this way automating the reporting system also require a thorough discussion to address it technically, accounting and managerial dimensions along with its potentiality in term of profit to be gained.

\section{RATIONALE OF THE STUDY}

As transformation is a continuous process, the concept of wealth in the last century has completely changed in the $21^{\text {st }}$ century. Everyone in the world has accepted the resource of the $21^{\text {st }}$ century as knowledge and information. The world is moving with so fast speed that it has become a great challenge to be with the time for the local firms. Local firms are to keep them on track to synchronize with the international players as the market has become boundary less. This situation imposes pressure upon the local firms to digitize their operations. As digitization is a technical process so special care should be taken regarding its potentiality and the requirements for safe installation. The investigation should be done upon the outcome and the benefit to be drawn by the major stakeholders who require a thorough and sensitive study to be undertaken. Associated risks and proper measures to address the same should also be brought into consideration to avoid the hazard of technology.

\section{RESEARCH QUESTION}

The researcher hopes to respond to the question in the study is mentioned below:

- To what extent can the accuracy, consistency, timeliness, integrity of financial reports be improved with the usage of IT?

\section{SCOPES OF THE STUDY}

This is the age of Information Technology. The size of the organizations is becoming larger in terms of employees and financial transactions. The transformation of the firms from manual to automation is a great challenge now. The span of supervision has been increased as it is easy to supervise maximum people with a minimum number of layers in the firms. Automation has a great impact on a firm's performance in terms of time and cost savings. New opportunities are explored by the application of IT in every functional department of the firm. Accordingly, the potential benefits are to be explored in the case of accounting discipline. As it is in initiation still now in Bangladesh so a lot of issues are to be discussed for getting most of the benefits from IT applications in accounting and finance. So the study will open new windows in the way to use IT for preparing financial reports. The organization will get directions and be benefited thereof. It will also help the investors to make decisions whether to invest or not.

\section{LITERATURE REVIEW}

Technology comes from the application of the invention of science. Technology not only brings blessing but also acts as a reason for suffering. Selase and Selase (2019) conducted research to see the need for technology for meeting the better business goal. Salehi and Torabi (2012) carried out a study named "The Role of Information Technology in Financial Reporting Quality: Iranian Scenario" to find out the impact of IT on financial reporting systems by hypothesis testing through T-Test, ANOVA, and Duncan's Test using an organized questionnaire. The finding of the study was that the relevance, reliability, and comparability of accounting information systems have been changed due to IT use. But according to Janardhanan (2020), a firm's values have been depended on some specific features of a firm like size, age, liquidity of the firm, and also an internal controlling system of firms, etc. Moreover, to adopt IFRS, the country's financial system has to gain convergence and also decline earnings management practices to make quality reporting (Kurfi, 2017; Amankwa, Mawutor, \& Yiadom, 2020). 
Imeokparia (2013) conducted a descriptive research" Information Technology and Financial Reporting by Deposit Money Bank in Nigeria: An Empirical Study" with a population size of 2,500 accountants and a sample size was taken as 345 from the population as primary data analyzed by simple regression model to examine the role of IT in the producing and publishing of financial reports of Deposit Money Banks in 2013 in Nigeria. She showed that the use of IT makes the reports more accurate, usable, and of better quality. She also proved that IT doesn't hinder compliance with the international standards of financial reporting. Saeidi and Prasad (2014) in their study "The Impact of Accounting Information Systems on Financial Performance - A Case Study of Tcs - India" considered Accounting Information Systems as such system where information can be processed from a different viewpoint and make an effective decision from operational level to strategic level for different kind of users. In this study, data has been collected from a primary source and processed by using automated data processing tools SPSS software for testing hypothesis, measuring P-value, and checking significant probability. Abdallah (2014) showed in his study that the impact of the use of the accounting information systems on the quality of financial statements provided to the Income and Sales Tax Department in Jordan. The study was conducted by the structured questionnaire comprising fourteen questions for 50 accountants as respondents. To analyze the collected data, some statistical tools like arithmetic mean, regression analysis, and standard deviations had to measure. This paper also tested the hypothesis using Cronbach's alpha test and simple linear regression test. The result of the study was that there is a positive relationship found between the impact when using the accounting information systems and the quality of financial statements. Murungi and Kayigamba (2015) in their study "The Impact of Computerized Accounting System on Financial Reporting in the Ministry of Local Government of Rwanda" recommends computerizes accounting system influences the financial reporting system in terms of accountability, timeliness, and friendliness, etc. The study was conducted based on primary data by constructing a survey questionnaire where 65 respondents were selected as samples randomly from a population of 110 . The study found that $38 \%$ of the respondents recommend accountability of financial reporting is increased by the use of computerized accounting, while $31 \%$ of the respondents recommend that the computerized accounting system producing financial statements on time. Eruemegbe (2015) in his study "Effect of Information and Communication Technology on Organization Performance in The Banking Sector "in 2015 gave his observation that ICT enables to increase the performance of banks profitability. The study also showed that the uses of ICT improve customer satisfaction and the delivery of services sharply. The study concluded with a significant positive relationship between technology innovations in service delivery. Olanrewaju (2016) in his study titled "Effects of Information Technology on Organizational Performance in Nigerian Banking Industries" in 2016 revealed that the performance of employees, customers, and profitability of bank has been improved due to the uses of technological innovation. The study suggested that actual administration of IT will be for better customer satisfaction, employee performance, and improved profitability and to lead competitiveness in the banking sector of Nigeria. Barakat et al. (2020) conducted a study to assess the standard of internet financial reporting by investigating internet reporting and corporate governance in Palestine. Alabar and Agema (2014) in their study titled "Information and Communication Technology and Customer Satisfaction in the Nigerian Banking Industry" discussed that the present situation of ICT had played an important role in customer satisfaction. The study "Evaluation of The Effect of Using Computer Audit Systems on Audit Quality" in 2016 showed that the effectiveness of auditing software has depended on the size of audit firms in terms of audit quality (Kermani, Bigzadeh, \& Khodamipour, 2016). If the firm size is larger, the audit quality is higher using computer auditing software and vice versa. The study recommended that there is 
a positive relationship exists between the size of audited firms and the efficiency of the computer auditing system on the quality of audit actions.

\section{HYPOTHESIS DEVELOPMENT}

A Null Hypothesis has been tested to understand the nature of the relationship between IT and the quality of financial reporting.

H0: There is no significant relationship between the Quality of Financial Reporting with an adaption of automation in the banking sector of Bangladesh.

\section{METHOD}

In this section, the whole process of the study has been highlighted along with the methods and statistical analysis conducted in this research. This research has been conducted by a structured interview schedule to conduct a survey for collecting primary data regarding the impact of IT in preparation of financial reports in banks. The officers from the head office have been interviewed. Then on the basis of the results of the pilot survey, a questionnaire was prepared to explore the impact indeed. The questionnaire includes the perceptions of the management in using IT in preparing financial reports regarding Cost, Time, Accuracy, Relevance, Reusability, etc. Research methodology mediates between research questions and data and shows how the research questions are connected to research objectives.

\section{Population and Samples of the Study}

The population of the Study: The study is concerned with the application of Information Technology in preparing financial statements by the commercial banks of Bangladesh. So, the total number of commercial banks operating in the country who are using automated systems for preparing financial statements is the population of the study. Currently, there are 42 private, 6 states owned and 8 foreign banks working in the country among those total 50 are using an automated system. So, the population size is 50 .

\section{Sampling Design}

Sampling is a procedure which uses a small number of items from the entire population to make conclusions about the population. A sample can be defined as a subset or a small part of a population. The purpose of using sampling is to facilitate an estimate of some known characteristics of the population (Sekaran \& Bougie, 2010; Zikmund, 2010). Sampling design is two types as probability sampling and non-probability sampling. Probability sampling can define as each element in the population has a known chance or probability of being selected as a sample. Simple random sampling is best known for probability sampling. However, conducting this sampling is difficult and costly; nevertheless, it is a popular sampling technique where the research findings can be generalized from the sample.

Non-probability sampling does not have a known chance of being selected as a subject. This sampling does not allow the research findings to be generalized from the sample to the population. It does not allow the researchers to analyze sampling statistics which provide information about the precision of the research findings. However, non-probability sampling is easy to be administered and it tends less complicated and less time consuming than probability sampling (Sekaran \& Bougie, 2010; Zikmund, 2010; Cooper, Schindler, \& Sun, 2006). The present study was conducted based on a probability sampling design. 


\section{Sample Size}

Determination of sample size is a very crucial issue because the sample that is too large may waste time, money, and resource while samples that are too small may lead to an inaccurate result. On the basis of Anderson's random sampling technique, the numbers of respondents are determined. Since the population is known, the sample size is determined by using the formula (Anderson, 1996):

$$
n=\frac{\mathrm{N} \cdot \mathrm{p}(1-\mathrm{p})}{N \frac{B^{2}}{4}+\mathrm{P}(1-\mathrm{p})}
$$

Where,

$\mathrm{N}=$ Number of known populations

$\mathrm{p}=$ proportion belonging to specified Category

$(1-p)=$ Proportion not belonging to the specified category

$\mathrm{B}=$ Level of significance

$\mathrm{n}=$ Sample size

Table1 indicates an estimated sample size of 100, calculated based on Anderson's random sampling technique.

Table 1. Estimated sample size

$$
\begin{array}{rl|l}
n & =\frac{\mathrm{N} \cdot \mathrm{p}(1-\mathrm{p})}{N \frac{B^{2}}{4}+\mathrm{P}(1-\mathrm{p})} & \mathrm{Where} \\
\mathrm{N}=50 \\
n & =33.33 & \mathrm{p}=.5 \text { (Assumed) } \\
& =33 \text { (Approximately) } & (1-\mathrm{p})=.5 \text { (Assumed) } \\
\mathrm{B}=10 \% \text { (i.e, level of significance) }
\end{array}
$$

\section{Sources and Collection of Data}

The study has been conducted by collecting primary data.

\section{Primary Data Source}

For exploring the level of application of automated financial reporting, primary data were required which have been collected through a structured questionnaire.

The interview schedule contains questions regarding the accuracy of financial statements, time-saving, cost-saving, risk reduction, Improvements of efficiency, Regulatory Compliance, audit purpose, Reduction of Turnaround Time.

\section{ANALYSIS AND FINDINGS}

The dependent variable (Outcome variable) The Quality of Financial Reporting in automated financial reporting in the Banking Sector of Bangladesh. To test the significance of Quality of financial reporting in the banking sector, the study has been going through the used General Regression Model by OLS method which comprises different test like T, F, R-square, Adjusted R-square as well as effects of related factor. 
Table 2. Coefficients

\begin{tabular}{|c|c|c|c|c|c|c|}
\hline \multirow{2}{*}{\multicolumn{2}{|c|}{ Model }} & \multicolumn{2}{|c|}{$\begin{array}{l}\text { Unstandardize } \\
\text { d Coefficients }\end{array}$} & \multirow{2}{*}{$\begin{array}{l}\text { Standardized } \\
\text { Coefficients } \\
\text { Beta }\end{array}$} & \multirow[t]{2}{*}{$\mathbf{T}$} & \multirow[t]{2}{*}{ Sig. } \\
\hline & & \multirow{2}{*}{$\begin{array}{l}\mathbf{B} \\
-.005\end{array}$} & \multirow{2}{*}{\begin{tabular}{|l|}
$\begin{array}{l}\text { Std. } \\
\text { Error }\end{array}$ \\
.918 \\
\end{tabular}} & & & \\
\hline 1 & (Constant) & & & & -.006 & .996 \\
\hline & Positive_Impact_IT & -.471 & .189 & -.506 & -2.494 & .020 \\
\hline & Operational_Knowledge & .251 & .162 & .335 & 1.554 & .133 \\
\hline & Produce_Req.Inf_Timely & -.216 & .199 & -.215 & -1.088 & .287 \\
\hline & Save.Cost_Inf.Sharing & -.372 & .379 & -.168 & -.980 & .337 \\
\hline & Save.Cost_Documentaion & .128 & .291 & .077 & .441 & .663 \\
\hline & $\begin{array}{l}\text { Outweigh.Benefits_Cost.of. } \\
\text { IT }\end{array}$ & .472 & .210 & .431 & 2.253 & .034 \\
\hline & Reliability.Increased.by_IT & .383 & .261 & .274 & 1.466 & .156 \\
\hline & Accuracy.Obtained.by_IT & .702 & .476 & .297 & 1.474 & .153 \\
\hline & $\begin{array}{l}\text { Maintain.Compliance.Reg. } \\
\text { Authority }\end{array}$ & .150 & .301 & .098 & .497 & .624 \\
\hline
\end{tabular}

Dependent Variable: Quality of Financial Reporting

Table 3. Correlation Matrix

\begin{tabular}{|c|c|c|c|c|c|c|c|c|c|c|c|}
\hline & & $\begin{array}{l}\text { Quali } \\
\text { ty of } \\
\text { Fina } \\
\text { ncial } \\
\text { Repo } \\
\text { rting }\end{array}$ & $\begin{array}{l}\text { Posit } \\
\text { ive_I } \\
\text { mpa } \\
\text { ct_I } \\
\text { T }\end{array}$ & $\begin{array}{l}\text { Oper } \\
\text { ationa } \\
\text { l_Kno } \\
\text { wledg } \\
\text { e }\end{array}$ & $\begin{array}{l}\text { Produ } \\
\text { ce_Re } \\
\text { q.Inf_- } \\
\text { Timel } \\
\text { y }\end{array}$ & $\begin{array}{l}\text { Save. } \\
\text { Cost_I } \\
\text { nf.Sha } \\
\text { ring }\end{array}$ & $\begin{array}{l}\text { Save. } \\
\text { Cost__ } \\
\text { Docu } \\
\text { menta } \\
\text { ion }\end{array}$ & $\begin{array}{l}\text { Outw } \\
\text { eigh. } \\
\text { Benef } \\
\text { its_C } \\
\text { ost.of } \\
\text {.IT }\end{array}$ & $\begin{array}{l}\text { Relia } \\
\text { bility } \\
\text {.Incr } \\
\text { ease } \\
\text { d.by } \\
\text { _IT }\end{array}$ & $\begin{array}{l}\text { Accu } \\
\text { racy. } \\
\text { Obtai } \\
\text { ned.b } \\
\text { y_IT }\end{array}$ & $\begin{array}{l}\text { Maint } \\
\text { ain.Co } \\
\text { mplia } \\
\text { nce.Re } \\
\text { g. } \\
\text { Autho } \\
\text { rity }\end{array}$ \\
\hline \multirow[t]{5}{*}{$\begin{array}{l}\text { Corr } \\
\text { elati } \\
\text { on }\end{array}$} & $\begin{array}{l}\text { Quality } \\
\text { of } \\
\text { Financia } \\
1 \\
\text { Reportin } \\
\text { g }\end{array}$ & 1.000 & -.208 & .028 & -.081 & .053 & .178 & .274 & .260 & .250 & .186 \\
\hline & $\begin{array}{l}\text { Positive } \\
\text { _Impact } \\
\text { IT }\end{array}$ & -.208 & 1.000 & .484 & .165 & -.070 & -.003 & .485 & .234 & -.276 & -.325 \\
\hline & $\begin{array}{l}\text { Operatio } \\
\text { nal_Kno } \\
\text { wledge }\end{array}$ & .028 & .484 & 1.000 & .501 & -.039 & .166 & .221 & .230 & -.323 & -.371 \\
\hline & $\begin{array}{l}\text { Produce } \\
\text { _Req.Inf } \\
\text { _Timely }\end{array}$ & -.081 & .165 & .501 & 1.000 & .020 & .236 & -.064 & .352 & -.064 & -.153 \\
\hline & $\begin{array}{l}\text { Save.Co } \\
\text { st_Inf.Sh }\end{array}$ & .053 & -.070 & -.039 & .020 & 1.000 & .142 & .076 & .101 & .350 & .285 \\
\hline
\end{tabular}




\begin{tabular}{|c|c|c|c|c|c|c|c|c|c|c|c|}
\hline & aring & & & & & & & & & & \\
\hline & $\begin{array}{l}\text { Save.Co } \\
\text { st_Docu } \\
\text { mentaio } \\
n\end{array}$ & .178 & -.003 & .166 & .236 & .142 & 1.000 & -.020 & .341 & .140 & -.090 \\
\hline & $\begin{array}{l}\text { Outweig } \\
\text { h.Benefi } \\
\text { ts_Cost. } \\
\text { of.IT }\end{array}$ & .274 & .485 & .221 & -.064 & .076 & -.020 & 1.000 & .294 & -.177 & -.139 \\
\hline & $\begin{array}{l}\text { Reliabili } \\
\text { ty.Increa } \\
\text { sed.by_I } \\
\mathrm{T}\end{array}$ & .260 & .234 & .230 & .352 & .101 & .341 & .294 & $\begin{array}{l}1.00 \\
0\end{array}$ & -.074 & -.114 \\
\hline & $\begin{array}{l}\text { Accurac } \\
\text { y.Obtain } \\
\text { ed.by_IT }\end{array}$ & .250 & -.276 & -.323 & -.064 & .350 & .140 & -.177 & -.074 & 1.000 & .541 \\
\hline & $\begin{array}{l}\text { Maintain } \\
\text {.Compli } \\
\text { ance.Re } \\
\text { g. } \\
\text { Authorit } \\
\text { y }\end{array}$ & .186 & -.325 & -.371 & -.153 & .285 & -.090 & -.139 & -.114 & .541 & 1.000 \\
\hline $\begin{array}{l}\text { Sig. } \\
(1- \\
\text { taile } \\
\text { d) }\end{array}$ & $\begin{array}{l}\text { Quality } \\
\text { of } \\
\text { Financia } \\
1 \\
\text { Reportin } \\
\text { g }\end{array}$ & & .119 & .438 & .325 & .384 & .157 & .059 & .069 & .077 & .146 \\
\hline & $\begin{array}{l}\text { Positive } \\
\text { _Impact } \\
\text { IT }\end{array}$ & .119 & & .002 & .176 & .346 & .492 & .002 & .091 & .057 & .030 \\
\hline & $\begin{array}{l}\text { Operatio } \\
\text { nal_Kno } \\
\text { wledge }\end{array}$ & .438 & .002 & & .001 & .412 & .174 & .105 & .096 & .031 & .015 \\
\hline & $\begin{array}{l}\text { Produce } \\
\text { _Req.Inf } \\
\text { _Timely }\end{array}$ & .325 & .176 & .001 & & .456 & .090 & .360 & .021 & .360 & .194 \\
\hline & $\begin{array}{l}\text { Save.Co } \\
\text { st_Inf.Sh } \\
\text { aring }\end{array}$ & .384 & .346 & .412 & .456 & & .212 & .336 & .285 & .021 & .051 \\
\hline & $\begin{array}{l}\text { Save.Co } \\
\text { st_Docu } \\
\text { mentaio } \\
n\end{array}$ & .157 & .492 & .174 & .090 & .212 & & .455 & .024 & .215 & .306 \\
\hline & $\begin{array}{l}\text { Outweig } \\
\text { h.Benefi }\end{array}$ & .059 & .002 & .105 & .360 & .336 & .455 & & .046 & .158 & .217 \\
\hline
\end{tabular}




\begin{tabular}{|l|l|l|l|l|l|l|l|l|l|l|}
\hline $\begin{array}{l}\text { ts_Cost. } \\
\text { of.IT }\end{array}$ & & & & & & & & & & \\
\hline $\begin{array}{l}\text { Reliabili } \\
\text { ty.Increa } \\
\text { sed.by_I } \\
\text { T }\end{array}$ & .069 & .091 & .096 & .021 & .285 & .024 & .046 & & .339 & .260 \\
\hline $\begin{array}{l}\text { Accurac } \\
\text { y.Obtain } \\
\text { ed.by_IT }\end{array}$ & .077 & .057 & .031 & .360 & .021 & .215 & .158 & .339 & & .000 \\
\hline $\begin{array}{l}\text { Maintain } \\
\text { Compli } \\
\text { ance.Re } \\
\text { g.Author } \\
\text { ity }\end{array}$ & .146 & .030 & .015 & .194 & .051 & .306 & .217 & .260 & .000 & \\
\hline
\end{tabular}

The significance value 0.02 for the variable "positive impact of IT" and The significance value of 0.03 for the variable "Outweigh Benefits of acquiring cost of IT software" which are less than 0.05 for the above 02 variables indicates that the test is significant and we can reject the null hypothesis. Which implies that there is a significant relationship between Quality of Financial Reporting with an adaption of automation in the banking sector of Bangladesh for these variables? And for remaining all other variables have positive relation but insignificant.

Table 4. ANOVA

\begin{tabular}{|c|c|c|c|c|c|c|}
\hline \multicolumn{2}{|c|}{ Model } & \multirow{2}{*}{\begin{tabular}{|l|l|}
$\begin{array}{l}\text { Sum of } \\
\text { Squares }\end{array}$ \\
16.545
\end{tabular}} & Df & \multirow{2}{*}{\begin{tabular}{|l}
$\begin{array}{l}\text { Mean } \\
\text { Square }\end{array}$ \\
1.838
\end{tabular}} & \multirow{2}{*}{$\frac{\mathbf{F}}{1.919}$} & \multirow{2}{*}{$\frac{\text { Sig. }}{.098}$} \\
\hline 1 & Regression & & 9 & & & \\
\hline & Residual & 22.985 & 24 & .958 & & \\
\hline & Total & 39.529 & 33 & & & \\
\hline
\end{tabular}

Table 5. Model Summary

\begin{tabular}{|c|c|c|c|c|c|}
\hline \multirow[b]{2}{*}{$\begin{array}{l}\text { R } \\
\text { Square }\end{array}$} & \multirow{2}{*}{$\begin{array}{l}\text { Adjusted R } \\
\text { Square }\end{array}$} & \multirow{2}{*}{$\mid \begin{array}{lr}\text { Std. } & \text { Error } \\
\text { of } & \text { the } \\
\text { Estimate }\end{array}$} & \multicolumn{3}{|c|}{ Change Statistics } \\
\hline & & & $\begin{array}{l}\text { R Square } \\
\text { Change }\end{array}$ & F Change & df1 \\
\hline .419 & .200 & .97862 & .419 & 1.919 & 9 \\
\hline
\end{tabular}

a. Predictors: (Constant), Maintain. Compliance.Reg. Authority, Save.Cost_Documentaion, Outweigh.Benefits_Cost.of.IT, Produce_Req.Inf_Timely, Save.Cost_Inf.Sharing, Reliability.Increased.by_IT, Positive_Impact_IT, Accuracy.Obtained.by_IT, Operational_Knowledge b. Dependent Variable: Quality of Financial Reporting 
From Table 5, it has been seen that the value of the Correlation coefficient (r) equal to 0.65 , shows the positive relationship between the dependent variable $\&$ independent variable. Again the value of $\mathrm{R}^{2}$ (Co-efficient of determinant) 0.42 , express that, the $42 \%$ of the variation of the dependent variable is occurred by the change of independent the variable. But the Adjusted $\mathrm{R}^{2}$ indicates the actual variation of the dependent variable is $20 \%$ out of $42 \%$ variation suggested by $\mathrm{R}^{2}$. To test the significance of overall variation of the model as well as to test the significance of goodness of fit of the model, F-test has been used. Here since the value of F-statistic 1.19 is greater than the table value of 0.098 at $5 \%$ levels of significance, so the test is significant.

From table 2, by using Student-t (T-test), it has been seen that the significance of individual parameters used in the model of the variables considered at a $5 \%$ level of significance.

\section{Normal P-P Plot of Regression Standardized Residual}

\section{Dependent Variable: Quality of Financial Reporting}

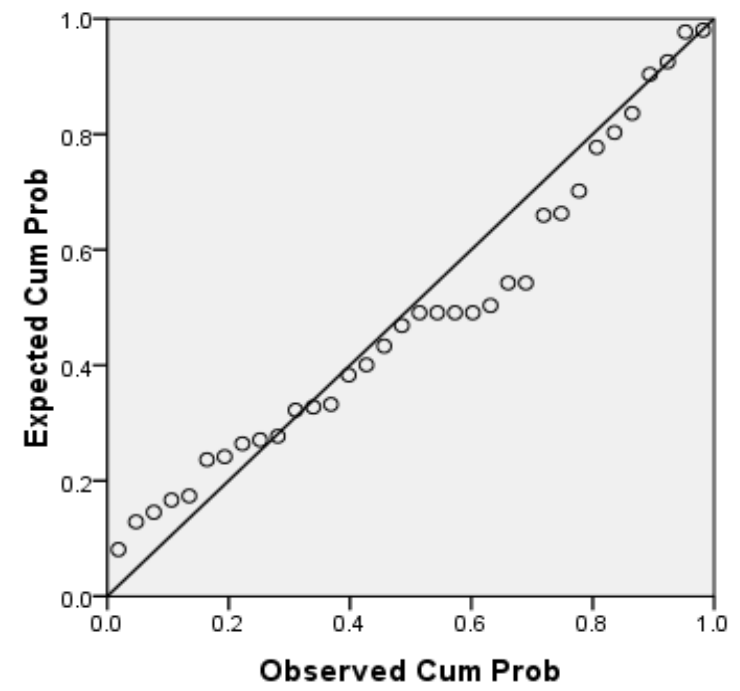

Figure 1. Normal P-P Plot of Regression Standardized Residual

Hence considering the above observations and significance $\&$ goodness of fit of the model between variables, it is said that the Quality of Financial Reporting has a significant relationship with an adaption of automation in the banking sector of Bangladesh.

\section{CONCLUSION}

The computerized reporting system has been demonstrated to be effective in providing and publishing information concerning the financial situation for a business in an efficient manner. It also enables data to be available instantly and be made available to different users in different locations at the same or different time zone. Moreover, we live in the age of science and enjoy the new discoveries of science through technology. The computer has high-speed processing logic that turned it into technology. From the study, it has been observed that qualities of information that are needed to produce better quality 
reporting for business are accuracy, timeliness, completeness, reliability, etc. The study also recommended that computerized systems have a positive impact on the quality of financial reports for better business purposes.

\section{REFERENCES}

Abdallah, A. A. J. (2014). The Impact Of Using Accounting Information Systems On The Quality Of Financial Statements Submitted To The Income And Sales Tax Department In Jordan. European Scientific Journal, ESJ, 9(10). https://doi.org/10.19044/esj.2013.v9n10p\%p

Anderson, J. R. (1996). ACT: A simple theory of complex cognition. American psychologist, 51(4), 355.

Alabar, T. T. \& Agema, R. J. (2014). Information and Communication Technology and Customer Satisfaction in the Nigerian Banking Industry, Journal of Advanced Management Science, 2(4), 333-338. https://doi.org/10.12720/joams.2.4.333-338

Amankwa, R. F., Mawutor, J. K. M., \& Yiadom, E. B. (2020). A Panel Examination of IFRS Adoption and Financial Statement Quality: Evidence from Selected Firms in Ghana. International Journal of Accounting \& Finance Review, 5(2), 45-53. https://doi.org/10.46281/ijafr.v5i2.768

Barakat, F. S. Q., Perez, M. V. L., Ariza, L. R., Barghouthi, O. A., \& Islam, K. M. A. (2020). The Impact Corporate Governance On Internet Financial Reporting: Empirical Evidence From Palestine. International Journal of Accounting \& Finance Review, 5(4), 1-22. https://doi.org/10.46281/ijafr.v5i4.852

Cooper, D. R., Schindler, P. S., \& Sun, J. (2006). Business research methods (Vol. 9, pp. 1-744). New York: Mcgraw-hill.

Eruemegbe, G. O. (2015). Effect of Information and Communication Technology on Organization Performance in The Banking Sector. International Journal of Research in Engineering \& Technology (IMPACT: IJRET), 3(4), 13-22.

Imeokparia, L. (2013). Information technology and financial reporting by deposit money bank in Nigeria: an empirical study. Research Journal of Finance and Accounting, 4(11), 39-47.

Janardhanan, A. K., \& R, U. V. (2020). The Role of Internal Control and Firm-Specific Characteristics on Firm Value: Evidence from Indian Financial Services Sector. Indian Journal of Finance and Banking, 4(1), 117-133. https://doi.org/10.46281/ijfb.v4i1.612

Kermani, A. Z., Bigzadeh, D. F. \& Khodamipour, A. (2016). Evaluation of the effect of using computer audit systems on audit quality, International Journal of Humanities and Cultural Studies, special issue, (pp. 1818-1835)

Kurfi, S. A. (2017). Adoption of International Financial Reporting Standard in Nigerian: The Good, the $\mathrm{Bad}$ and the Ugly. Indian Journal of Finance and Banking, 1(1), $42-61$. https://doi.org/10.46281/ijfb.v1i1.84 
Murungi, S. \& Kayigamba, C. (2015). The impact of computerized accounting system on financial reporting in the ministry of local government of Rwanda. Journal of Emerging Trends in Economics and Management Sciences, 6(4), 261-265.

Olanrewaju, B. E. (2016). Effects of information technology on organizational performance in Nigerian banking industries. Research Journal of Finance and Accounting, 7(3), 52-64.

Saeidi, H., \& Prasad, B. (2014). Impact of accounting information systems (AIS) on organizational performance: A case study of TATA consultancy services (TCS)-India. Journal of Management and Accounting Studies, 2(03), 54-60.

Salehi, M., \& Torabi, E. (2012). The Role of Information Technology in Financial Reporting Quality: Iranian Scenario. Poslovna izvrsnost, 6(1), 127-127.

Sekaran, U., \& Bougie, R. (2010). Research methods for business: A skill-building approach (5th ed.). Haddington: John Wiley \& Sons.

Selase, A. M., \& Selase, A. E. (2019). The Pros and Cons of Adopting Technology as a Business Pilot: Global Perspective. Indian Journal of Finance and Banking, 3(2), 1-4. https://doi.org/10.46281/ijfb.v3i2.388

Zikmund, W. G. (2010). Business Research Methods, Mason, OH: South-Western Cengage Learning, 2010.

\section{APPENDICES}

Appendix A: Percentage Distribution of Respondents on Variables

\begin{tabular}{|l|l|l|l|l|l|l|l|}
\hline S1 No & Statement & $\begin{array}{l}\text { SA } \\
(\%)\end{array}$ & $\begin{array}{l}\text { A } \\
(\%)\end{array}$ & $\begin{array}{l}\text { U } \\
(\%)\end{array}$ & $\begin{array}{l}\mathrm{D} \\
(\%)\end{array}$ & $\begin{array}{l}\text { SD } \\
(\%)\end{array}$ & $\begin{array}{l}\text { CUMM } \\
(\%)\end{array}$ \\
\hline 1 & Role of IT in the reporting process & 37.8 & 45.6 & 7.9 & 8.9 & 00 & 100 \\
\hline 2 & $\begin{array}{l}\text { Information technology has a positive } \\
\text { impact on the performance of my bank }\end{array}$ & 41.1 & 43.3 & 4.4 & 6.7 & 4.4 & 100 \\
\hline 3 & $\begin{array}{l}\text { We have the technical know-how to } \\
\text { operate the IT in my bank }\end{array}$ & 25.6 & 52.22 & 11.1 & 8.9 & 2.2 & 100 \\
\hline 4 & $\begin{array}{l}\text { Information technology in my bank } \\
\text { produces required information timely. }\end{array}$ & 72.3 & 26.7 & 1.0 & 00 & 00 & 100 \\
\hline 5 & $\begin{array}{l}\text { IT saves cost in Information sharing } \\
\text { IT saves cost saving in Documentation }\end{array}$ & 60.3 & 36.7 & 1.0 & 00 & 00 & 100 \\
\hline 6 & $\begin{array}{l}\text { The cost of acquiring information } \\
\text { technology in my bank outweighs its } \\
\text { benefits }\end{array}$ & 36.7 & 45.6 & 1.1 & 15.6 & 1.1 & 100 \\
\hline 7 & Reliability of reports is increased by & 70 & 30 & 00 & 00 & 00 & 100 \\
\hline 8
\end{tabular}




\begin{tabular}{|c|c|c|c|c|c|c|c|}
\hline & adopting IT & & & & & & \\
\hline 9 & $\begin{array}{l}\text { Increased accuracy is obtained by } \\
\text { applying IT }\end{array}$ & 69.5 & 30.5 & 00 & 00 & 00 & 100 \\
\hline 10 & $\begin{array}{l}\text { IT helps to maintain compliance with } \\
\text { the regulatory authority }\end{array}$ & 25.6 & 51.1 & 23.3 & 00 & 00 & 100 \\
\hline
\end{tabular}

Source: Field Survey, 2019

Key: SA = Strongly Agree A = Agree U = Undecided SD =Strongly Disagree D = Disagree

\section{Copyrights}

Copyright for this article is retained by the author(s), with first publication rights granted to the journal. This is an open-access article distributed under the terms and conditions of the Creative Commons Attribution license (http://creativecommons.org/licenses/by/4.0/) 